\title{
II. Meşrutiyet Döneminden Cumhuriyet'in Kuruluş Yıllarına Halkçılık Fikrinin Gelişimi
}

ERKAN DOĞAN*

do.erkan@gmail.com

ORCID-ID: 0000-0002-0928-3049

Öz: Türkiye’de halkçılı̆̆ın kökenlerini II. Meşrutiyet dönemine kadar götürebilmemiz mümkündür. Bu ideolojinin ilk biçimlerini Ziya Gökalp ve Yusuf Akçura gibi Türk milliyetçisi entelektüellerin yazılarında görebiliriz. Bu açıdan bakıldığında, Türkiye'de, halkçılı̆̆ın bu erken dönem tarihinin kaderi Türk milliyetçiliğinin tarihi tarafından belirlenmiştir. Halkçılı, Türk milliyetçiliğini oluşturan ve besleyen önemli unsurlardan bir tanesidir. Dayanışma (tesanüt) kavramının Gökalp tarafından, Durkheim sosyolojisi yoluyla, halkçılı̆̆n söylemine katılmasıyla birlikte Türk halkı, imtiyazsız ve sinıfsiz bir kitle olarak tahayyül edilmeye başlanmıştır. Bu miras erken Cumhuriyet döneminin yönetici elitleri tarafından devralınmıştır.

Anahtar kelimeler: Halkçılık, Dayanışma, Milliyetçilik, II. Meşrutiyet Dönemi, Erken Cumhuriyet Dönemi.

\section{Giriş}

Kemalizmin altı okundan biri olan ve 1937 yılında diğer beş ilkeyle beraber anayasada yer alan halkçılık ilkesinin Türkiye’deki kökenlerini II. Meşrutiyet yıllarına kadar götürmek mümkündür. Kemalizmin halkçılık ilkesinin, II. Meşrutiyet döneminin Türkçü aydınlarının formüle ettiği halkçılık anlayışından ödünç aldığı çok şey olmuştur. Halkçılığın II. Meşrutiyet'ten Cumhuriyet'in kuruluş yıllarına uzanan tarihsel gelişimi içerisinde çeşitli kırılmalara uğramış, ilk ortaya çıktığı anda sahip olduğu içeriğin yerini, zaman içinde farklı bir içerik almış, halkçılık kavramı yeni kurulan cumhuriyet rejiminde yeni işlevler üstlenmiştir.

Halkçılık fikrini Osmanlı entelektüel hayatına sokan isimlerin aynı zamanda Türkçülüğün önde gelen savunucuları olması II. Meşrutiyet ve erken cumhuriyet dönemi halkçılığını karakterize eden önemli bir gelişme olarak görülebilir. Bu dönemin halkçılık anlayışı, Türk milliyetçiliğini oluşturan ve onu besleyen unsurlardan biri olarak

* Dr. Öğr. Üyesi, Kocaeli Üniversitesi, İ̇̉BF, Siyaset Bilimi ve Kamu Yönetimi Bölümü. 
karşımıza çıkar. Bu açıdan bakıldığında halkçılığın bu topraklardaki erken dönem tarihini milliyetçiliğin tarihinden ayırabilmek pek mümkün görünmemektedir. Halkçllı̆̆n izlerini ilk ortaya çıtığı dönemlerde Gökalp, Akçura gibi isimlerin çalışmalarında, Yeni Felsefe Mecmuası, Genç Kalemler, Türk Yurdu, Halka Doğru gibi dergilerde, Türk Ocağı, Milli Talim ve Terbiye Cemiyeti gibi oluşumlarda görmek şaşırtıcı değildir. Bu çalışmada, Türkiye'de halkçılığın II. Meşrutiyet’ten Cumhuriyet dönemine kadar kat ettiği gelişimin niteliği Türk milliyetçiliği ile ilişkisi içerisinde anlaşılmaya çalışlacaktır.

\section{Türkiye'deki Halkçılığın Kökenleri}

Niyazi Berkes II. Meşrutiyet döneminde ortaya çıkan halkçılık ideolojisinin, 19. yüzyılda şekillenmiş olan Rus popülizminin (narodnizm) Osmanlıya ulaşan serpintilerinden etkilendiğini belirtir. Berkes'in haklı olarak gözlemlediği gibi, burada ilginç olan, fikirsel düzeyde Batı Avrupadan beslenen Osmanlı aydınlarının şimdiye kadar kendi düşünsel dünyaları üzerinde hiç etkisi olmamış olan başka kaynaktan gelen fikirlerden (dolaylı da olsa) etkilenmiş olmalarıdır. Berkes’e göre Rusya'daki halkçılık hareketinin Osmanlı aydınları üzerindeki etkisi üç dolaylı yoldan gerçekleşmiştir: Bir taraftan Rus halkçıllı̆ından etkilenmiş olan Balkan ve özellikle Bulgar aydınları yoluyla, diğer taraftan Hüseyinzade Ali gibi Rusya’dan gelen Türk kökenli aydınlar vasıtasıyla ve son olarak Ermeni aydınlarının başlattığı sosyalist Hınçak akımının

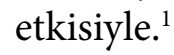

II. Meşrutiyet dönemi halkçıllğının ortaya çıkmasında etkili olmuş olan Rus narodnizmi ${ }^{2}$ Kırım savaşı ve Rusya’da köleliğin kaldırılması ile doğmuş, 1860 'lı ve 70'li yıllarda güç kazanmıştır. 1881'de Çar II. Alexandır'ın öldürülmesi ile doruğa ulaşmış, bundan sonra hızla gerileşmiştir. Rus narodnizmi teorik ifadesini Herzen, Çernişevski, Lavrov, Bakunin, Tkacev, Mihaylovski gibi düşünürlerin savunduğu görüşlerde bulmuştur. Bu düşünürlerin savunduğu ortak düşünce "köylü sosyalizmi" idi. Bu yaklaşıma göre Rusya kapitalist aşamayı atlayarak köylülük aracıllğıyla sosyalizme varabilirdi. Andrzej Walicki 19. yüzyılda Rus devrimci hareketine damgasını vurmuş olan Rus popülizmini şöyle tanımlamaktadır: “Popülizm' terimine birden çok ve farklı anlamlar yüklenmiştir. Sözcügün en geniş anlamıyla 'popülizm', köylülerin ve küçük üreticilerin çıkarlarını dile getirmiş olan ve Rusyảnın kapitalist gelişme aşamasını geçirmesinin zorunlu olmayıp, bu aşamayı atlayabileceği görüşünü savunan, ister reformcu isterse devrimci tüm Rus demokratik ideolojilerine verilen addir." $^{3}$

II. Meşrutiyet dönemindeki aydınlara da esin kaynağı olan Rusyadaki "halka doğ-

1 Niyazi Berkes, Türk Düşününde Batı Sorunu, Ankara: Bilgi Yayınevi, 1975, s.230-232. Bu konuda ayrıca bakınız, İlhan Tekeli ve Gencay Şaylan, “Türkiye’de Halkçılık İdeolojisinin Evrimi”, Toplum ve Bilim, 6-7 (1978), s.57-58; Zafer Toprak, "II. Meşrutiyet’te Solidarist Düşünce: Halkçıllk", Toplum ve Bilim, 1 (1977), s.92-93.

2 Rus narodnizmi konusundaki değerlendirmeler için bakınız, M. Asım Karaömerlioğlu, "Rus Popülizmi Üzerine”, Toplum ve Bilim, 88 (2001); Franco Venturi, Roots of Revolution: A History of the Populist and Socialist Movements in 19th Century Russia, New York: Grosset \& Dunlap, 1966; Andrzej Walicki, Rus Düşünce Tarihi: Aydınlanma'dan Marksizmee, çev., Adam Şenel İstanbul: İletişim Yayınları, 2009.

3 Walicki, Rus Düşünce Tarihi, s.341. 
ru” hareketi bu yıllarda doğmuştu. Bu hareketin çekimine kapılmış Rus aydınları, köylüleri kendi fikirlerine kazanmak için kitleler halinde kırsal bölgelere akın ettiler. Venturi bu dönemin Rus popülistlerinin ruh halini şu çarpıcı sözlerle aktarmaktadır: “1874’teki 'Çıllgın Yaz' diye bilinen dönem boyunca yüz binlerce genç erkek ve kadın... evlerini, zenginliklerini, ünlerini ve ailelerini terk etti. Neşe, coşku ve kişinin hayatı boyunca bir kez duyabileceği ve kaybedince bir daha bulamayacağı bir inanç ile kendilerini harekete adadılar. Fakat ortada henüz bir siyasal hareket yoktu. Bu daha çok bir dini hareket gibiydi ve böyle bir hareketin tüm bulaşıcılığını taşıyordu. $\mathrm{Bu}$ sadece pratik bir sonuca ulaşma uğraşı değil, aynı zamanda derinden duyulan bir görevi yerine getirme uğraşı, ahlaki bir mükemmellik arzusu idi.”4

II. Meşrutiyet dönemi halkçılığını etkileyen bir dizi kaynağın ortak esin noktası Rus narodnizmiydi. Bu açıdan bakıldığında halkçılığın Türkiye'deki bu erken dönemi Rus narodnizminden dolaylı olarak etkilenmişti ve bu etkiyi mesela o dönemde önde gelen entelektüellerin kullanıma soktuğu "halka doğru" kavramında görebilmekteyiz. Bununla beraber, birincisi birçok yönüyle ikincisinden ayrılmaktaydı. Bir kere Rus halkçılığı, düşünsel ve siyasal düzeyde devlet iktidarından görece bağımsızlaşmış muhalif aydınların bir ürünüydü ve amaçlarına ulaşma konusunda oldukça radikal bir siyaset yapma tarzını benimsemişlerdi. Daha önemlisi bu hareket, her ne kadar Batı türü bir kapitalizme ve yine Batı türü bir sosyalizm anlayışına karşı olmuşsa da, alt sınıfların ve özellikle köylülerin çıkarlarını savunan bir tür Rusya’ya özgü sosyalizm anlayışını benimsemişlerdi. Bu haliyle kendilerini kısmi reform talepleriyle sınırlandırmamışlar, Çarlık rejiminin topyekûn bir değişimini arzulamışlardı.

II. Meşrutiyet döneminin halkçılığına bakıldığında bu özelliklerin pek geçerli olduğunu söylemek mümkün görünmemektedir. Türk halkçılığı bir değişim ve modernleşme anlayışına sahipti ama Rusya örneğinde olduğu gibi köklü ve radikal bir sosyal ve siyasal değişim öngörmemişti. Değişimin öznesi olarak modernleşmeci bürokratik-entelektüel elit görülüyordu. Ayrıca, halkçılık anlayışlarını toplum içindeki sınıf farklılıklarını ve çatışmalarını absorbe edecek güçlü bir milliyetçilik söylemiyle beslemişlerdi. Bu farklılaşmaya neden olan şey II. Meşrutiyet halkçılığının Rus narodnizminden sonra gelen bir diğer kaynağında aranmalıdır: Fransız solidarizmi. İleriki sayfalarda daha ayrıntılı olarak ele alınacağı gibi halkçılık kavramı, dönemin önde gelen entelektüellerinden olan Gökalp'in söyleminde solidarist korporatizm kavramıyla birlikte birbirlerinin yerine kullanılabilecek şekilde ele alınmıştır. Fransız sosyolugu Durkheimden ilham alınarak oluşturulmuş bu tesanütçülük anlayışı temel olarak hem liberalizme hem de Marksizm’e karşı çıkmaktaydı. Türkiye'de Batıdaki şekliyle modern sınıfların varlığ 1 reddedilmekte ve farklı toplum kesimlerinin her birinin kendine özgü sorumluluğunu yerine getirdiği milli bir dayanışma fikri savunulmaktayd.

Türkiye'deki erken dönem halkçılığının aldığı bu şekli daha genel bir sosyal ve ekonomik analiz çerçevesinde ele alan kimi yorumlar, Türkiye’nin kendine özgü kapitalistleşme (ve daha genel anlamda modernleşme) sürecinin sebep olduğu koşullar

4 Venturi, Roots of Revolution, s.503. 
ve bunları aşmak için halkçıllı̆ın ideolojik ve siyasal bir araç olarak kullanması ihtiyacına referansla açıklar. Mesela, Tekeli ve Şaylan halkçılık ideolojisinin Türkiye topraklarındaki şekillenişini belirleyen temel sürecin Türkiyede kapitalizmin gelişimi olduğunu ifade ederler. Halkçılığın kapitalizmin gelişimi sırasında mülksüzleşme tehlikesiyle karşı karşıya kalan orta sınıfların tepkisinden kaynaklandığını, genel olarak halkçlık ideolojisini bu sınıfların dünyaya bakış açısı olarak değerlendirmek gerektiğini belirtirler. ${ }^{5}$ Türkiye'de popülizmin entelektüel ve siyasal olmak üzere iki evresinden bahseden Toprak, 1908-50 arası dönemin entelektüel bir halkçllk süreci olduğunu, takip eden halkçllığın ise siyasal bir nitelik taşıdığını belirtir. Halkçılığın genel olarak geciken kapitalizmin sebep olduğu koşulların bir ürünü olduğunu ifade eden Toprak, entelektüel boyut taşıyan birinci dönem halkçıllğını kastederek, bu halkçıllğın "bir ulus-devlet oluşum sürecinde 'küçük burjuva' diye nitelendirilebilecek, kapitalist yapılanmada gecikmeden ve uyumsuzluktan kaynaklanan, ancak gelenekçi olduğu kadar köktenci öğeleri de içeren, kente düşman köye dost, ulusal değerleri kırda arayan, sınıfları yadsıyan dayanışmacı" bir tür popülizm olduğunu belirtir. ${ }^{6}$ Sınıfları yadsıyan bu türden bir halkçılığın milliyetçilikle eklemlenmesi pek şaşırtıcı değildi. Köker, Türkiyedeki halkçılık anlayışının da içine sokulabileceği "Üçüncü Dünya popülizmi”nin, halkçı öğelerle milliyetçiliği birleştirdiğini, bu anlayışın millet ve halkı özdeşleştirdiğini belirtmektedir. ${ }^{7}$ Köker, bu popülist milliyetçiliği (ya da milliyetçi popülizmi) "ortaya çıktığı toplumların çoğunda var olan içsel bölünmeleri, farklllıkları, hatta eşitsizlikleri, bütünleşmiş bir siyasal topluluğu ifade edecek biçimde oluşturulan millet kavramıyla aşma çabası olarak" değerlendirmektedir. ${ }^{8}$

\section{Meşrutiyet Döneminde Halkçılık}

Selanik, 1908'den sonra (bir Osmanlı şehri olmaktan çıktığı 1912'ye kadar) İmparatorluğun siyasi ve fikir merkezlerinden biri olmuştu. Dönemin en önemli siyasi organizasyonu olan İttihat ve Terakki Cemiyeti'nin merkezi, 1912 yllında İstanbul'a taşınana kadar Selanik'teydi. Toprak’ın deyimiyle, "Osmanlı topraklarında fikir hareketleri açısından İstanbul'a rakip kent Selanik'ti.” II. Meşrutiyet dönemi halkçılığının ilk örneklerini bu şehirde bulmak bu açıdan şaşırtıcı değil. Selanik’te çıkan ve Ömer Seyfettin, Ziya Gökalp, Ali Canib gibi isimlerin yayınladığ 1 Genç Kalemler ve Yeni Felsefe Mecmuası dergileri "yeni hayat" düsturu etrafında hem lisani Türkçülügün hem de halkçıl lğın ilk örneklerini vermişlerdi. Selanik’teki Türkçülük yaklaşımı, yine bu şehirde ortaya çıkan yeni lisan anlayışını merkezine almıştı. Yeni hayat (yeni iktisat, yeni aile, yeni felsefe, yeni, ahlak, yeni siyaset, yeni hukukla beraber) yeni bir lisanı gerektiriyordu ve arayış ancak halka doğru giderek realize edilebilirdi. ${ }^{10}$

Selanik’te ortaya çıkan Türkçülükle harmanlanmış bu halkçılık yaklaşımının bir

5 Tekeli ve Şaylan, “Türkiye’de Halkçllık İdeolojisinin Evrimi”, s.46.

6 Zafer Toprak, "Popülizm ve Türkiyedeki Boyutları", Tarih ve Demokrasi: Tarık Zafer Tunaya'ya Armağan, İstanbul: Cem Yayınevi, 1992, s.62-63.

7 Levent Köker, Modernleşme, Kemalizm ve Demokrasi, İstanbul: İletişim Yayınları, 1993, s.116.

8 Köker, Modernleşme, Kemalizm ve Demokrasi, s.117.

9 Zafer Toprak, Türkiye'de Popülizm: 1908-1923, İstanbul: Doğan Kitap, 2013, s.117.

10 "Yeni hayat" kavramı için bakınız Ziya Gökalp, Terbiyenin Sosyal ve Kültürel Temelleri I, İstanbul: Milli Eğitim Basımevi, 1973, s.261-269. Ayrıca bakınız, Toprak, Türkiye'de Popülizm, s.122-162. 
benzer versiyonu yine aynı zamanlarda İstanbul'da ortaya çıkmıştı. ${ }^{11} \mathrm{Bu}$ konudaki ilk ciddi adım Ağustos 1911'de Türk Yurdu Cemiyeti'nin kurulmasıyla atılmıştı. Kurucuları arasında Mehmet Emin Yurdakul, Ahmet Ağaoğlu, Hüseyinzade Ali, Yusuf Akçura gibi isimlerin olduğu dernek bir süre sonra kendini lağvedip Mart 1912'de kurulan yeni bir derneğe Türk Ocağı'na katılmış ve yeni derneğin yayın organı da Türk Yurdu adını almıştı. ${ }^{12}$ Panslavizm ve Rus popülizminden etkilenmiş olarak Rusyadan gelip Osmanlı fikir hayatına katılan Müslüman aydınlar bu erken dönem Türkçülüğünün ve halkçılığın oluşmasında bu cemiyetler ve yayın faaliyetleri yoluyla önemli bir rol oynamışlardı. Halkçılığın ve Türkçülüğün Osmanlıdaki kaynaklarına ilişkin bir değerlendirmede bulunduğu Yeni Mecmua’da yayınlanan bir yazısında bu rolü teyyit eden Ziya Gökalp, Hüseyinzade Ali'yi kastederek şunları söylemektedir: "Ali Bey Petersburg Darülfünunu’nda iki tesir altında kalmıştı: Panslavizm, sosyalizm. Ali Bey Panslavizmden Pantürkizm mefkuresini çıkardığı gibi, sosyalizmden de halkçılık ahlakını aldı." ${ }^{33}$ Bu dönem halkçılığının öne çıkardığı "halka doğru" kavramı bir süre sonra bir süreli yayına dönüştü ve Nisan 1913'den Nisan 1914'e kadar Türk Yurdu dergisinin bir eki olarak yayınlandı. Onu takip eden süreli yayın Türk Sözü'nün mottosu ise "halka doğru gitmek ve halk için çalışmak" idi.

Merkezinde Yusuf Akçura’nın bulunduğu Türk Yurdu etrafında şekillenen bu yayın faaliyetlerinin içinde Ziya Gökalp, Ömer Seyfettin, Mehmet Emin Yurdakul, Ahmet Ağaoğlu, Hüseyinzade Ali, Mehmet Fuat Köprülü gibi dönemin önde gelen Türkçü ve halkçı entelektüelleri yer almaktayd1. ${ }^{14} \mathrm{Bu}$ isimler II. Meşrutiyet dönemi halkçılı̆̆ açısından önemli sayılabilecek bir yayın olan Halka Doğru dergisinde de yazmaktaydı. Türk Yurdu'nun içinden çıkan Halka Doğru dergisinin yayınlanmak istenmesinde, Akçura’ya göre, milli bilinç ve ruhun daha geniş halk kesimlerine de yayılmasına hizmet etmek isteği bulunmaktadır. ${ }^{15}$ Akçura, aydınlar ve halk arasındaki ilişki hakkındaki görüşlerini kaleme aldığı "Halka" başlıklı bir dizi makalede "halkın içinde yaşayan, ona yardımcı olan, onunla konuşan dertlerini dinleyen, sorularına cevap veren” bir yaklaşımı yüceltiyordu. Akçura, "Biz Halka Doğru diye ad taktığımız bu cerideyi halk için, halka faydal olmak için çıkarıyoruz" diyordu. ${ }^{16}$ Halkın karşı karşıya kaldığ 1 sorunların çözülebilmesi için, halka giderek ona önderlik edebilecek okumuş insanlara ihtiyaç vardı. Bu konuda Türk halkçılarına örnek olarak Sırp, Bulgar ve Rum aydınlarını gösteriyordu: “Atina’da öğrenimini tamamlayan genç Osmanlı Rumları Anadolu’ya dönüp köylere ve kasabalara kadar gidiyorlar, oralarda okullar

\footnotetext{
11 Toprak, Selanik’te Genç Kalemler ve Yeni Felsefe Mecmua dergileri etrafında oluşan Türk milliyetçiliği ile İstanbul'da Türk Yurdu etrafında şekillenen milliyetçilik akımı arasındaki farklara dikkat çeker ve şu değerlendirmeyi yapar: "Selanik yitirildikten sonra İstanbul'daki 'yurtçuluk’la Selanik’teki reel Türkçülük kaynaşacak, ancak Selanik daha sonraki gelişmelerde hâkim konuma gelecekti.” Toprak, Türkiye’de Popülizm, s.138.

12 Türk Yurdu ve Türk Ocağı cemiyetleri ve Türk Yurdu dergisi için bakınız Füsun Üstel, Imparatorluktan UlusDevlete Türk Milliyetçiliği: Türk Ocakları 1912-1931, İstanbul: İletişim Yayınları, 2004, s.15-68.

13 Bu ifade Göaklap’in “Türkçülük Nasıl Doğdu?” makalesinde yer alır. Bu makale için bakınız, Ziya Gökalp, Yeni Mecmua Yazıları, İstanbul: Ötüken Yayınevi, 2018, s.311-318.

14 Akçura ve Türk Yurdu’na ilişkin olarak bakınız, François Georgeon, Türk Milliyetçiliğinin Kökenleri: Yusuf Akçura (1876-1935), İstanbul: Tarih Vakfı Yurt Yayınları, 1996, s.67-71.

15 Georgeon, Türk Milliyetçiliğinin Kökenleri, s.108.

16 Aktaran Toprak, Türkiye'de Popülizm, s.173.
} 
açıyorlar, eğitim ve tıp konusunda öğrendiklerini yayıyorlar; bir başka deyişle halka gidiyorlar. Rumların hastalıklarına deva olacak ilaçlar veriyorlar ve cehaleti ortadan kaldırmaya çalışıyorlar." ${ }^{17}$

Niyazi Berkes, Türkiyedeki halkçllığın bu erken aşamasında, Türk milliyetçiği ve halkçlık (ve sosyalizm) arasındaki ilişkiyle ilgili olarak ilginç bir değerlendirmede bulunur. Berkes, meşrutiyetin ilk yıllarında Genç Kalemler ve Yeni Felsefe Mecmuası etrafında şekillenen Yeni Hayat çevresinin halkçılık akımının ilk temsilcisi olduğunu ve sosyalizan eğilimler barındığını iddia eder, Genç Kalemler dergisi etrafında şekillenen halkçılık, halk ile devlet (ve aydınlar) arasındaki uçurumu esasen bir dil meselesi olarak görmekte, bu nedenle aydınların halk diline dönmesi gerektiğini savunmaktadır. Berkes’e göre Genç Kalemler "Türkçülük fikrinin öncüsü olarak gösterilir. Bu ancak kısmen doğrudur; çünkü onun asıl yansıttığı fikir halkçılıktır." ${ }^{18}$

Berkes, II. Meşrutiyet ile beraber aydınların önceki yıllarda olduğu gibi yine esas olarak Osmanlıcılık, İslamcılık ve Batıcılık akımları içinde yer aldıklarını ama bu tarihle beraber ilk defa bir dördüncü akımın, toplumculuğun, aydınlar arasında güç bulduğunu, bu toplumculuğun kendisini halkçılık olarak gösterdiğini belirtmektedir. ${ }^{19}$ Berkes, yeni şekillenmeye başlayan bu halkçılığın temelsiz Osmanlı milliyetçiliğinden kurtulma çabasının bir ürünü olarak değerlendirmektedir. ${ }^{20}$ Bir tür romantik karakter taşısa da, zaman zaman kendisini dilcilik çalışmalarıyla sınırlandırsa da (çünkü dönemin halkçıları halk ile aydınlar arasındaki uçurumun aydınların halk diline dönmesiyle aşılacağını düşünmekteydiler) bu ilk dönem halkçılığı, bir düzeyde sınıfsal ve toplumcu bir içerik taşımakta; aydınların halka yönelmesi, onunla bütünleşmesi, onu aydınlatması gerektiğini savunmakta, böylelikle halkın sorunlarına çözüm bulunacağını belirtmekteydi.

Fakat sosyalizan karakterler taşıyan, bu haliyle Rus narodniklerinin halkçılık anlayışıyla çeşitli düzeylerde benzerlikler gösteren hareket etkisini yavaş yavaş yitirdi ve yerini Türkçülük akımına bırakmaya başladı. Berkes’e göre diğer düşünce akımları içerisinde yer alan kimselerin, yeni şekillenmekte olan halkçılığa yönelik saldırıları daha doğum aşamasında olan bu yeni fikirleri bir tür mutasyona uğratmıştı: "Uyducu Batıcılar, Osmanlıcılar, İslamcılar, yani bütün alafranga aydınlar halkçılara hakaret ya da alay etmek için onlara 'Türkçü' adını taktılar. ('Türk' o zaman kaba cahil halk demekti. Osmanlıcılarla İslamcılar okumuş kibar kişiler olduklarından kendilerini Türk saymazlardı.) Halkçılık yavaş yavaş Türkçülük-milliyetçilik-kavmiyetçilik-ırkçılık olarak tanınmaya başladı. 'Halk'çıların kendileri de yavaş yavaş bunları birbirine karıştırmaya başladılar.” ${ }^{21}$ Halkçıların uğradığı düşünsel mutasyonda etkili olan yalnızca söz konusu üç akımın taraftarları değildi. Diğer taraftan, bu dönemin halkçılarının, Rusya'dan göç eden Türk asıllı entelektüellerin milliyetçi fikirlerinden yoğun bir biçimde etkilenmeleri, aynı zamanda halktan uzak oluşları ve toplumsal

17 Georgeon, Türk Milliyetçiliğinin Kökenleri, s.110.

18 Berkes, Türk Düşününde Batı Sorunu, s.62.

19 Berkes, Türk Düşününde Batı Sorunu, s.229-30.

20 Berkes, Türk Düşününde Batı Sorunu, s.61.

21 Berkes, Türk Düşününde Batı Sorunu, s.235. 
sınıflarla organik bağlar kuramamaları onların yaşadığı düşünsel dönüşümü hızlandirmaktaydi. ${ }^{22}$

Bu koşullar altında gelişme imkânı bulamayan halkçılık akımının kendisini bir tür mayın tarlası içinde bulduğunu belirten Berkes, Ziya Gökalp’in, "halkçılık akımını, bu mayın tarlalarında dolaştıra dolaştıra yeden güçlü bir düşün, kavram ve terim ustası olarak" ortaya çıktığını belirtmektedir. ${ }^{23}$ Halkçılık anlayışı, Türkçülük anlayışına doğru kaydıkça ve artık Türkçülügün ülkülerinden biri olarak tarif edilmeye başlandıkça Gökalp’in fikirleri Yeni Hayat çevresi içerisinde daha etkin hale gelmekteydi. Türkçülüğün Esaslar kitabında, Türkçülügün ilk unsurlardan birinin halka doğru ilkesi olduğunu belirtir Gökalp. ${ }^{24}$ Halka doğru gitmesi gerekenler ona göre bu miiletin aydınlarıdır. Aydınlarda medeniyet, halkta ise milli kültür vardır. Dolayısıyla halka gitmenin iki amacı bulunmaktadır: "harsın canlı bir müzesi" olan "halktan harsi bir terbiye almak için" ve "halka medeniyet götürmek için." ${ }^{25}$ Aydınların aldıkları eğitim milli kültürden yoksundu, okudukları okullar halk okulları, milli okullar değildi. $\mathrm{Bu}$ nedenle, "milletimizin güzideleri milli harstan mahrum olarak yetiştiler, gayri millileşerek yetiştiler." ${ }^{26}$ Bu gayrı milliliğin ilacı halka gitmek, halkın içine girmek ve halkla yaşamaktı. ${ }^{27}$ Bunun karşılığında münevverler halka değerli bir armağan olarak Batı medeniyetini götürmeliydi. Yine aynı kitabında milli mücadele yıllarını kastederek şunları söylemektedir: “Türkiye’de Tanrı’nın kılıcı halkçıların pençesinde ve Tanrı’nın kalemi Türkçülerin elindeydi. Türk Yurdu tehlikeye düşünce, bu kılıçla bu kalem birleştiler... Gelecekte de daima halkçılıkla Türkçülük ele ele verip ülküler âlemine doğru birlikte yürüyeceklerdir. Her Türkçü siyasal alanda halkçı kalacaktır. Her halkçı da kültür alanında Türkçü olacaktır... Siyasette uğraşımız halkçılık ve kültürde uğraşımız Türkçülüktür." ${ }^{28}$

Gökalp halkçılığı yeni biçimiyle tarif ederken ihtiyaç duyduğu kavramsal araçları genel olarak Fransız solidarist düşüncesinden ${ }^{29}$, özel olarak da Durkheim’nn fikirle-

22 Berkes, Türk Düşününde Batı Sorunu, s.235-36.

23 Berkes, Türk Düşününde Batı Sorunu, s.236.

24 Ziya Gökalp, Türkçülüğün Esasları, Varlık Yayınevi: İstanbul, 1968, s.40.

25 Gökalp, Türkçülüğün Esasları, s.42.

26 Gökalp, Türkçülüğün Esasları, s.43.

$27 \mathrm{Bu}$ uzun alıntı Gökalp’in milli kültüre ulaşmak için halka gitmekle neyi kastettiğini anlamamıza yardım edecek nitelikte: "Ne yapmalıdır? Bir taraftan halkın içine girmek, halkla beraber yaşamak, halkın kullandığı kelimelere, cümlelere dikkat etmek. Söylediği darbımeselleri, an’anevi hikmetleri işitmek. Düşünüşündeki tarzı, duyuşundaki üslûbu zapt etmek. Şiirini, musikisini dinleyerek, raksını, oyunlarını seyretmek. Dinî hayatına, ahlâkî duygularına nüfuz etmek. Giyinişinde, evinin mimarî- v sinde, mobilyalarının sadeliğindeki güzellikleri tadabilmek. Bundan başka, halkın masallarını, fıkralarını, menkıbelerini öğrenmek. Halk kitaplarını okumak. Korkut Ata’dan başlayarak âşık kitaplarını, Yunus Emre'den başlayarak tekke ilahilerini, Nasreddin Hoca'dan başlayarak orta oyununu aramak bulmak lâzım. Halkın cenknameler okunan eski kahvelerini, ramazan gecelerini, cuma arifelerini, çocukların her sene sabırsızlıkla bekledikleri coşkun bayramlarını yeniden diriltmek, canlandırmak lâzım. Halkın sanat eserlerini toplayarak millî müzeler vücuda getirmek lâzım. İşte, Türk milletinin güzideleri, ancak uzun müddet halkın bu millî hars müzeleri ve mektepleri içinde yaşadıktan ve ruhları tamamıyla Türk. harsiyle meşbu olduktan sonradır ki, millileşmek imkânına nail olabilirler.” Gökalp, Türkçülüğün Esasları, s.43

28 Gökalp, Türkçülüğün Esasları, s.166.

29 Zafer Toprak Fransız solidarizmini, "teşebbüs serbestiyeti ve mülkiyetin dokunulmazlığına gölge düşürmeden liberalizmle sosyalizm arası bir 'orta yol' aramayı amaçlayan, ekonomide devlet müdahaleciliğini öneren, sosyal mevzuatı gündemine alan, toplumsal yaşamda sınıf çatışmasının gereksizliğine inanan, çelişkiden arınmış, 
rinden ödünç almıştı. Berkes’e göre Gökalp, "halkçllığı Marksist sosyalizmden ayırarak Durkheim’n sosyolojizmine bulayıp ondan tam Osmanlı İmparatorluğunun batacağı sıralarda 'tesanütçülük' dediği solidarizm ve mesleki temsilcilik ilkesine ulaştırd.." ${ }^{30}$ Gökalp’in müdahalesiyle yeni bir anlam kazanan halkçllık artık dönemin uluslaşma sürecini, milli iktisat politikasını ve toplumsal dayanışma ilkesini kapsayan bir ideoloji haline geldi.

Gökalp’in halkçllğga verdiği yeni içeriğin en ilgi çekici taraflarından biri de bu yeni haliyle halkçılı̆̆ın artık sınıfsal bir bakış açısını dışlamasıdır. Toprak ilginç bir gözlemde bulunarak, II. Meşrutiyet'in ilk yarısında şekillenen halkçıllğıın dünya savaşıyla birlikte yeni bir evreye girdiğini; savaş öncesi halkçılığının halk kavramını sınıfsal bir bağlamda kullandığını ve alt gelir gruplarına yönelik bir içeriğe sahip olduğunu belirtmektedir. Dünya savaşıyla birlikte durum değişmiş, kavram bir tür değişime uğrayıp sınıfsal içeriğini kaybetmiştir. ${ }^{31}$

Durkheim’nn toplumsal dayanışma anlayışına dayanan Gökalp halkçıllğı birbirleriyle çelişen toplumsal sinıflar yerine uzlaşan meslek zümrelerini koymakta, sınıf mücadelesini yadsıyarak, meslek grupları arasında uyum ve dayanışmaya öngörmektedir: "Bir cemiyetin dâhilinde bir takım tabakaların yahut sınıfların bulunması, dâhili müsavatın bulunmadığını gösterir. Binaenaleyh, halkçılığın gayesi, tabaka ve sınıf farklarını kaldırarak, cemiyetin birbirinden farklı zümrelerini, yalnız işbölümünün doğurduğu meslek zümrelerine hasretmektir. Yani halkçllı, felsefesini bu düsturda icmal eder: Sınıf yok meslek var!’32 Durkheim’ın korporatist dayanışmacıllğından hareket eden Gökalp’e göre, sınıf çatışmaları devrini meslek devri izleyecek; sınıf çatışmaları devrinin halkçılığı olan siyasal halkçılığın yok edemediği toplumsal sınıfları, bir sonraki devrin, meslek devrinin, halkçılık anlayışı yani toplumsal halkçılık ortadan kaldıracaktır. ${ }^{33}$

\section{Erken Cumhuriyet Döneminde Halkçılık}

II. Meşrutiyet döneminin halkçılık anlayışının kendi içinde yaşadığı bu dönüşüm ve ulaştığı sonuçlar, cumhuriyet dönemi halkçıllğının şekillenmesinde çeşitli düzeylerde etkili olmuş, bu kavramı değişen koşullar içerisinde yeniden kullanıma sokmak isteyen Cumhuriyet kadroları için bir kalkış noktası olmuştur.

Milli mücadele yıllarında ve onu takip eden erken Cumhuriyet döneminde halkçılık kavramı çeşitli biçimlerde gündemde kalmaya devam etmiştir. Milli mücadele yıllarında, bu mücadelenin önder kadroları farklı sosyal sınıfların desteğini almak, bu mücadeleye destek veren Sovyetler Birliği ile yakınlaşmayı sağlamak gibi gerekçe-

uzlaşma esasına dayalı organik dayanışmayı (tesanüdü) benimseyen, laik eğitimi savunan, pasifist, uzlaşmacı bir ideoloji” olarak tanımlamaktadır. Toprak, "II. Meşrutiyet’te Solidarist Düşünce”, s.95.

30 Berkes, Türk Düşününde Batı Sorunu, s.237. Solidarizm hakkında Gökalp şunları söylemektedir: "Türkler, hürriyet ve istiklâli sevdikleri için, iştirakçi olamazlar. Fakat, müsavatperver olduklarından dolayı, fertçi de kalamazlar. Türk harsına en uygun olan sistem solidarizm, yani tesanütçülüktür." Gökalp, Türkçülüğün Esasları, s.162.

31 Zafer Toprak, “Osmanlı Narodnikleri: 'Halka Doğru' Gidenler”, Toplum ve Bilim, 24(1984), s.75.

32 Aktaran Toprak, “II. Meşrutiyet’te Solidarist Düşünce”, s.92.

33 Zafer Toprak, “Türkiye’de Korporatizmin Doğuşu”, Toplum ve Bilim, 12(1980), s.43-44. 
lerle halkçılık kavramını siyasal söylemlerinde ön planda tutmayı tercih etmişlerdir. Bu dönem aynı zamanda sol içerikli bir söyleme sahip siyasi çevrelerin de milli mücadele içerisinde etkili oldukları yıllardır. Hareket içerisindeki bu muhalefetin etkisini azaltmak isteyen milli mücadelenin merkezindeki kadrolar açısından halkçılığın siyasal tartışmalarda ön plana geçmesinin, pragmatik gayeler de taşıdığı söylenebilir. Fakat hangi gerekçelerle olursa olsun milli mücadelenin sürdüğü 1920'lerin başında halk, halkçılık, halk egemenliği, halk hükümeti gibi kavramlar hem resmi metinlerde, hem de meclis içindeki tartışmalarda karşımıza çıkmaktaydı. Ocak 1921'de kabul edilen Teşkilat-1 Esasiye Kanunu’nun ilk maddesi, "Hâkimiyet bilâ kaydü şart milletindir. İdare usulü halkın mukadderatını bizzat ve bilfiil idare etmesi esasına müstenittir”34, egemenliğin kaynağı olarak halka işaret ediyordu. Aralık 1921'de mecliste yaptığı bir konuşmasında Mustafa Kemal Teşkilat-1 Esasiye Kanunu'na referans veriyor, "bizim hükümetimiz... hâkimiyet-i milliyyeyi, irade-i milliyyeyi yegâne tecelli ettiren bir hükümettir... İlmî, içtimai noktasından bizim hükümetimizi ifade etmek lâzım gelirse; 'Halk hükümeti' deriz” diyordu. Aynı konuşmada halkçılıkla ilgili olarak şunları söylüyordu:

Fakat mesleki içtimai itibariyle dahi düşündügümüz zaman biz hayatını, istiklâlini kurtarmak için çalışan erbab-ı sayız, zavallı halkız. Mahiyetimizi bilelim. Kurtulmak, yaşamak için çalışan ve çalışmaya mecbur olan bir halkız. Binaenaleyh, her birimizin hakkı vardır. Salâhiyeti vardır. Fakat çalışmak sayesinde biz hakkı iktisab ederiz. Yoksa arka üstü yatmak ye hayatını say'dan muarra geçirmek isteyen insanların bizim heyeti içtimaiyyemiz içerisinde yeri yoktur, hakkı yoktur. O halde ifade ediniz efendiler; halkçılık, nizamı içtimaisini say'ıne, hukukuna istinad ettirmek isteyen bir mesleki içtimaidir. ${ }^{35}$

Milli mücadelenin kazanılmasından sonra, yeni bir devletin ve rejimin kurulduğu yıllarda halkçılık, sınıfsal farklılıkları reddeden, milleti kaynaşmış bir bütün olarak gören yaklaşımı destekleyen bir prensip olarak tanımlanmaya başlandı. Halk Fırkası'nın daha cumhuriyetin ilanından önceki aylarda oluşturulmuş olan 1923 tarihli tüzüğünün "Umumi Esaslar” başlığı atında toplanmış olan maddelerinde, fırkanın siyasal hattını belirleyen yaklaşımın halkçılık olduğu belirtilmiştir. Burada halkçılık sınıfsal ayrımları dışlayan, sınıflar üstü, hiç bir gruba imtiyaz tanımayan ve vatandaşların kanun önünde eşitliğini savunan bir anlayış olarak tarif edilmiştir. Halk Fırkası'nın 1923 tüzügünde halkçılıkla ilgili olarak şunlar yazmaktadır: "Hiçbir imtiyaz iddiasında bulunmayan ve umumiyetle kanun nazarında mutlak bir müsavatı kabul eden bütün fertler halktandır. Halkçılar, hiçbir ailenin, hiçbir sınıfın, hiçbir cemaatin, hiçbir ferdin imtiyazlarını kabul etmeyen ve kanunları vaz'etmekteki mutlak hürriyet ve istiklali tanıyan fertlerdir." ${ }^{36}$ Halkçılık partinin daha sonraki yıllarda kaleme alınan resmi metinlerinde de benzer (hatta aynı) biçimlerde tanımlanmıştır. Partinin 1927 tarihli tüzügünde halkçılık şöyle tarif edilmiştir: "Fırka... kanun nazarında mutlak bir müsavatı kabul eden ve hiçbir ailenin ve hiçbir sınıfın, hiçbir ce-

34 https://anayasa.tbmm.gov.tr/docs/1921/1921ilkmetin/1921-ilkhali.pdf.

35 Aktaran, Toprak, Türkiye'de Popülizm, s.409.

36 Aktaran, Taha Parla, Kemalist Tek-Parti İdeolojisi ve CHP’nin Altı Oku, İstanbul: İletişim Yayınları, 1995, s.25. 
maatin, hiçbir ferdin imtiyazlarını tanımayan fertleri halktan ve halkçı olarak kabul eyler." ${ }^{37} 1931$ tarihli parti programında yapılan halkçılık tanımı bu tarifin nerdeyse aynisidir. ${ }^{38}$

Cumhuriyet Halk Partisi'nin hem memlekette hem de mecliste iktidar tekelini tek başına elinde tuttuğu, tek parti iktidarının kurumsallaşmasına yönelik temel adımların atıldığı 1930'lu yıllarda halkçılık anlayışına daha korporatist bir içerik kazandırılmıştır. Sınıf mücadelesini tamamen yadsıyan, meslek grupları arasında dayanışmayı öngören, toplumsal dayanışma anlayışına bağlı bir halkçılık fikri Kemalist tek-parti yönetiminin temel dayanaklarından biri haline gelmiştir. Partinin 1931 programında, klasik Kemalist halkçılık tanımının yanı sıra, bu tanımı tamamlayıcı nitelikte açıklamalar yer almaktadır. Programda halkın ayrı ayrı sınıflardan oluşan bir topluluk olmadığı fakat iş bölümü içerisinde "muhtelif mesai erbabına ayrılmış bir camia" olduğunun altı çizilmekte, Gökalp’in “sınıf yok meslek var” sözünden esinlenerek "sınıf yok işbölümü var" denilmektedir. ${ }^{39}$ Parla’ya göre sınıf farklılıklarını, hatta onların varlığını bile reddeden bu korporatist halkçılık anti-liberal ve anti-sosyalist bir içeriğe sahiptir. ${ }^{40}$

"Sınıf yok, işbölümü var" diyen parti, bu işbölümünün ortaya çıkardığ zümreleri”nin içerisine küçük çiftçileri, küçük sanayi erbabı ve esnafı, amele ve işçiyi, serbest meslek erbabını, büyük arazi ve iş sahiplerini ve tüccarları katmaktadır. Bu sinıflandırmayla amaçlanan sınıf mücadelesi yerine "içitimai intizam ve tesanüt temin etmek... ve menfaatlerde ahenk tesis eylemek”tir. ${ }^{41}$ Fakat Parla’nın haklı olarak belirttiği gibi: "Bu sınıflandırmanın meslek zümreleriyle bir ilgisi yoktur; sosyal sınıf kesimleri, üretim ilişkilerindeki konumlarına göre tasnif edilmiştir. 'Sınıf yok' sloganı, aslında 'sınıf var, çatışma yok' demektir." ${ }^{42}$

Tekeli ve Şaylan’a göre tek-parti döneminin Durkheimcı dayanışma sosyolojisine dayanan halkçılık anlayışının tek-parti rejimi açısından işlevsel bir anlamı vardır: Eğer ülkede sinıflar ve dolayısıyla onlar arasında süren mücadeleler olsaydı bu toplumsal sınıfların çıkarlarını korumak için farklı farklı siyasal partilerin olması doğaldı. Fakat Türkiye topraklarında farklı sınıflar ve dolayısıyla onların birbiriyle çatışan çıkarları olmadığına göre iktidardakiler açısından başka partilere gerek yoktu. ${ }^{43} 1931$ y1lında parti genel sekreteri olan ve partinin bir düzeyde ideologluğuna soyunan Recep Peker, İnkılâp Dersleri’nde, halkçılık anlayışlarının sınıf ihtilaline, sınıf mücadelesini yaratan doktrinlere karşı olduğunu söylerken; halkçılık zihniyetlerinin ulusu birbirinden ayrılmaz bir bütün olarak kabul etmek anlamına geldiğini belirtmektedir. ${ }^{44}$ Halkı ulusla özdeşleştiren ve onu yekpare bir bütün olarak gören Peker şunları söylemektedir:

37 Cumhuriyet Halk Fırkası Nizamnamesi, İstanbul: Hakimiyeti Milliye Matbaas1, 1931, s.4.

38 Bakını, CHF Nizamnamesi ve Programı, Ankara: TBMM Matbaası, 1931, s.31.

39 CHF Nizamnamesi ve Programi, s.32.

40 Parla, Kemalist Tek-Parti İdeolojisi, s.42.

41 CHF Nizamnamesi ve Programi, s.32.

42 Parla, Kemalist Tek-Parti İdeolojisi, s.43.

43 Tekeli ve Şaylan, “Türkiye’de Halkçlılk İdeolojisinin Evrimi”, s.79.

44 Recep Peker, İnkılab Dersleri, Ankara: Ulus Basımevi, 1935, s.54. 
[B]ir takım zümre ve sınıfların kendi menfaatlerine uygun olarak öne sürmek isteyecekleri bir takım telakkilerden doğarak ulusun politika yaşayışında engeller ve muvaffakiyetsizlikler çıkaracak, dağınık, karışık partiler hayatının meydan alması ve devam etmesi; devletin bu kadar ihtisas, kıymet, güven, kafa, el ve gönül birliği isteyen çetin ve büyük işlerini zorlaştırmaktan, karıştırmaktan, $\mathrm{t}[\mathrm{ö}]$ kezletmekten başka şeye yaramaz. Her şey uluslaşmışken parti de uluslaşmalıdır: Liberal devlet tipinin dağınık partileri yerine ulusun bütün isteklerine omuzvermiş, bütün tehlikelerigöğüslemiş, yapanı ile, satanı ile, alanı ile, toprakta, fabrikada, lab[o] ratuvarda çalışanı ile, köyde ve ken[tt]e yaşayanı ile, bütün halk yığınlarının ihtiyaçlarını duyup anlayarak çalışma sinesinde bunlara yer ve değer vermiş, ulusal bir partili idarenin muvaffak olacağ $\left[\right.$ bir] devirdeyiz. ${ }^{45}$

Cumhuriyet dönemi halkçllı̆̆ının bir diğer özelliği ise devletçilik ilkesiyle olan ilişkisidir. Gökalp kendi kavramsallaştırması içerisinde halkçılığı, siyasal tabakalaşmaların kalmadığı ama iktisadi tabakalaşmanın varlığını sürdürdüğü siyasal halkçılık dönemi ve iktisadi tabaklaşmaları da ortadan kaldıracak toplumsal halkçılık dönemi olarak ikiye ayırmaktadır. Gökalp, toplumsal halkçılı̆̆ın sınıf farklarını ortadan kaldırmak için devletçilik anlayışından yararlanması gerektiğini belirtmektedir. Ona göre, bu aşamada devletçilik ve halkçlık birbirini tamamlayan bir ideolojik bütün oluşturmalıdır. Oysa Tekeli ve Şaylan’a göre cumhuriyet dönemi halkçıllı̆̆ı, devletçilik ve halkçılık ilkelerini birbirinden ayırmak konusunda titiz davranmış, devletçiliğin sınıf farklarının doğmaması ve halkçılığın gerçekleşmesi için bir araç olarak kullanılması fikrini benimsememiştir. ${ }^{46}$

1931 yllında parti programına konulan devletçilik ilkesi, bu programda, özel girişimcilik esas tutulmakla beraber kısa zamanda "milleti refaha ve memleketi mamuriyete eriştirmek için... -bilhassa iktisadi sahada- Devleti fiilen alakadar etmek" olarak tanımlanmaktadır. ${ }^{47} 1930$ 'larda devletçilik anlayışı etrafında iktidar bloğu içerisinde süren tartışmalarda ${ }^{48}$ taraflar devletçiliği geçici bir sistem olarak görmekle kalıcı bir sistem haline gelmesini savunmak arasında saflaşmış olmasına rağmen, her iki tarafın da ortak olarak savundukları yaklaşımlar vardır: Her iki taraf da devletçiliği yalnız iktisadi alanla sınırlamayı tercih etmekte ve özel girişimciliğin varlığını (değişen şiddetlerde de olsa) sürdürmesi gerektiğini savunmaktadır. Dolayısıyla tarafların hiçbiri aslında devletçiliği iktisadi alanla sınırlı olmayan bir toplumsal sistem olarak görmemekte, halkçllık anlayışıyla devletçilik ilkesi arasında bir ilişki kurmaya pek yanaşmamaktadır. Dolayısıyla ortada sınıf farklılaşmalarını, hatta sınıfları reddeden bir halkçılık anlayışı olmasına rağmen, bu amacı gerçekleştiricek yapısal adımlar atılmamaktadir.

$\mathrm{Bu}$ dönemin devletçilik tartışmalarında halkçılık ve devletçilik ilkeleri arasındaki ilişkiyi daha tutarlı bir hale getirmeye çalışan, devletçiliği salt bir iktisadi model olma-

45 Peker, İnkılab Dersleri, s.69-70.

46 Tekeli ve Şaylan, “Türkiye'de Halkçılık İdeolojisinin Evrimi”, s.63.

47 CHF Nizamnamesi ve Programi, s.31.

48 Dönemin devletçilik tartışmaları için bakınız, Korkut Boratav, Türkiye’de Devletçilik, Gerçek Yayınevi: İstanbul, 1974, s.164-226. 
nın ötesinde, bir toplumsal sistem olarak gören, dönemin Kadro dergisi çevresinin pozisyonu ilginçtir. ${ }^{49}$ İktidar bloğuyla dolaylı ilişkileri olan ve Kemalizme tutarlı bir ideolojik içerik kazandırmaya çalışan Kadrocular, sınıf farklılıklarını ve çatışmalarını reddeden tek-parti dönemi halkçılığının bu hedefinin devletçilik ilkesiyle beraber gerçekleştirilebilmesinin imkânlarının doğmuş olduğuna inanmaktadırlar. Köker'in belirttiği gibi Kadrocular, "devletçiliği, halkçılık ilkesinde içerilen sınıfsız, imtiyazsız, 'dayanışmacı' bir toplumun yaratılması amacıyla savunmaktadırlar.” Kadroculara göre "devletçiliğin gerekli kıldığı planlama, planlamada düzenlenecek olan işbölümü esasları, Türk toplumunun sınıfsızlığında temellenebilecek ve iktisadi kalkınmanın yaratabileceği sınıf çatışması da böylece engellenmiş olacaktır." ${ }^{50}$ Fakat Kadrocuların dönemin halkçılık anlayışını tutarlı bir ideolojik içeriğe kavuşturma çabaları iktidar tarafından onay bulmamış, iktidar kendi bildiği yolda ilerlemeye devam etmiştir.

\section{Sonuç}

Türkiye'de halkçılık anlayışının doğuşu ve dönüşümü ilginç bir seyir izlemiştir. Siyasal iktidara karşı gelişen muhalif bir ideoloji ve ezilen sınıfların çıkarlarının temsilcisi bir hareket olma özelliği göstermemiş olan halkçılık anlayışı, II. Meşrutiyet ve Cumhuriyet dönemlerinde iktidar bloğu içerisindeki ya da bu bloğa yakın olan aydınlar arasında etkili olmuş; bu dönemlerin siyasal iktidarlarının siyasal görüşlerinin önemli eksenlerinden birini oluşturmuştur. İlk şekillenmeye başladığı zamanlarda, Berkes'in ifadesiyle, sosyalizan bir boyut taşıyan halkçılık anlayışı, kısa zaman sonra bu özelliğini yitirmiş, daha çok Türkçülüğe, milliyetçiliğe doğru kaymış, sınıfları reddeden, toplumsal dayanışmacılık zemini üzerinden tarif edilmeye başlanmıştır. Halkçılığın II. Meşrutiyet yıllarında yaşadığı bu dönüşüm, Cumhuriyet yıllarında da ödünç alınmış, bu dönemin halkçılık anlayışının tarif edilmesinde kullanılmıştır. Milleti halkla özdeşleştiren, sınıf çatışmalarını ve hatta sınıfları yadsıyan bir halkçılığı benimseyen bu dönemin kadroları halkçılık ilkesini, aynı zamanda, dönemin tek-parti iktidarının meşrulaştırılmak için kullanmışlardı.

\section{Kaynakça}

Berkes, Niyazi. Türk Düşününde Batı Sorunu. Ankara: Bilgi Yayınevi, 1975.

Boratav, Korkut. Türkiye’de Devletçilik. İstanbul: Gerçek Yayınevi, 1974.

Cumhuriyet Halk Fırkası Nizamnamesi. Hakimiyeti Milliye Matbaası: İstanbul, 1931. CHF Nizamnamesi ve Programı. Ankara: TBMM Matbaası, 1931.

Georgeon, François. Türk Milliyetçiliğinin Kökenleri: Yusuf Akçura (1876-1935). İstanbul: Tarih Vakfı Yurt Yayınları, 1996.

Gökalp, Ziya. Türkçülüğün Esasları. İstanbul: Varlık Yayınevi, 1968.

Gökalp, Ziya. Terbiyenin Sosyal ve Kültürel Temelleri I. İstanbul: Milli Eğitim Basimevi, 1973.

Gökalp, Ziya. Yeni Mecmua Yazıları. İstanbul: Ötüken Yayınevi, 2018.

49 Kadrocular ve firkirleri için bakınız, Mustafa Türkeş, Kadro Hareketi, Ulusçu Sol Bir Akım, Ankara: İmge Kitabevi, 1999; İlhan Tekeli ve Selim İlkin, “Türkiye’de Bir Aydın Hareketi: Kadro”, Toplum ve Bilim, 24 (1984). 50 Köker, Modernleşme, Kemalizm ve Demokrasi, s.195. 
Karaömerlioğlu, M. Asım. “Rus Popülizmi Üzerine”. Toplum ve Bilim, 88 (2001): 235250.

Köker, Levent. Modernleşme, Kemalizm ve Demokrasi. İstanbul: İletişim Yayınları, 1993.

Parla, Taha. Kemalist Tek-Parti İdeolojisi ve CHP'nin Altı Oku. İstanbul: İletişim Yayınları, 1995.

Parla, Taha. Ziya Gökalp, Kemalizm ve Türkiye'de Korporatizm. İstanbul: İletişim Yayınları, 1999.

Peker, Recep. İnkılab Dersleri. Ankara: Ulus Basımevi, 1935.

Tekeli, İlhan ve Gencay Şaylan, “Türkiye’de Halkçılık İdeolojisinin Evrimi”. Toplum ve Bilim, 6-7 (1978): 44-110.

Tekeli, İlhan ve Selim İlkin, “Türkiyede Bir Aydın Hareketi: Kadro”. Toplum ve Bilim, 24 (1984): 35-67.

TeşkilatıEsasiyeKanunu,https://anayasa.tbmm.gov.tr/docs/1921/1921ilkmetin/1921ilkhali.pdf.

Toprak, Zafer. “II. Meşrutiyet’te Solidarist Düşünce: Halkçılık”. Toplum ve Bilim. 1 (1977): 92-123.

Toprak, Zafer. “Türkiye'de Korporatizmin Doğuşu”. Toplum ve Bilim, 12 (1980): 4149.

Toprak, Zafer. “Osmanlı Narodnikleri: 'Halka Doğru' Gidenler”. Toplum ve Bilim. 24 (1984): 69-81.

Toprak, Zafer. "Popülizm ve Türkiye’deki Boyutları". Tarih ve Demokrasi: Tarık Zafer Tunaya'ya Armağan, İstanbul: Cem Yayınevi, 1992.

Toprak, Zafer. Türkiye’de Popülizm: 1908-1923. İstanbul: Doğan Kitap, 2013.

Türkeş, Mustafa. Kadro Hareketi: Ulusçu Sol Bir Akım. Ankara: İmge Kitabevi, 1999.

Üstel, Füsun. Imparatorluktan Ulus-Devlete Türk Milliyetçiliği: Türk Ocakları 19121931. İstanbul: İletişim Yayınları, 2004.

Venturi. Roots of Revolution: A History of the Populist and Socialist Movements in 19th Century Russia. New York: Grosset \& Dunlap, 1966.

Walicki, Andrzej. Rus Düşünce Tarihi: Aydınlanma'dan Marksizme. Çev., Adam Şenel. İstanbul: İletişim Yayınları, 2009. 


\title{
The Evolution of Populism from the Second Constitutional Period to the Early Republican Era
}

ERKAN DOĞAN

\begin{abstract}
The origins of Turkish populism can be extended back to the Second Constitutional Period. We can find the first formulations of this ideology in the writings of nationalist intellectuals like Ziya Gökalp and Yusuf Akçura. In this sense, it can be argued that the fate of populism in the Turkish context is determined by the history of Turkish nationalism from its early stages on. Populism was considered as one key constituting element of Turkish nationalism. With the incorporation of the idea of solidarism into the populist idiom via Durkheimian sociology by Gökalp, Turkish people were imagined as an unprivileged and classless nation. This legacy was also continued by the ruling elite of the early Republican period.
\end{abstract}

Keywords: Populism, Solidarism, Nationalism, Second Constitutional Period, Early Republican Era. 